\title{
Farmer social connectedness and market access: A case study of personal networks among emerging farmers
}

\author{
Christian Kelly Scott a* \\ Michigan State University and Pennsylvania State University \\ Robert B. Richardson ${ }^{b}$ \\ Michigan State University
}

Submitted July 7, 2020 / Revised October 14 and November 2, 2020 / Accepted November 2, 2020 /

Published online March 25, 2021

Citation: Scott, C. K., \& Richardson, R. B. (2021). Farmer social connectedness and market access: A case study of personal networks among emerging farmers. Journal of Agriculture, Food Systems, and Community Development, 10(2), 431-453. https://doi.org/10.5304/jafscd.2021.102.024

Copyright (C) 2021 by the Authors. Published by the Lyson Center for Civic Agriculture and Food Systems. Open access under CC-BY license.

\begin{abstract}
Market access in the local food system of the American Midwest is largely predicated on key social and economic relationships. This study examines the personal networks of emerging farmers enrolled in an incubator farm training program. Drawing from social network and qualitative analysis the study findings yield insights into the relationship between social networks, market access, and financial sustainability among
\end{abstract}

\footnotetext{
a * Corresponding author: Christian Kelly Scott, Department of Community Sustainability, Michigan State University.

Scott is now a Ph.D. candidate in Rural Sociology and International Agriculture \& Development, Department of Agricultural Economics, Sociology, \& Education, Pennsylvania State University; 111 Armsby Building; University Park, PA 16802 USA; +1-814-865-0456; cks8@psu.edu; christiankscott@gmail.com

${ }^{b}$ Robert B. Richardson, Professor and Associate Chair, Department of Community Sustainability, Michigan State University; 480 Wilson Road; East Lansing, MI 48824 USA; +1-517-355-9533; rbr@msu.edu
}

emerging farmers. Some farmers have highly dense support networks with many strong familial ties. Others have smaller support networks characterized by weaker and more sparse ties. Highly individualized farmer characteristics and aspirations are shown to greatly influence the building and maintaining of networks. Advice networks are demonstrated to affect market access, decisionmaking, and indicators for entrepreneurial success. Smaller advice networks of non-English speaking farmers demonstrate limited market access and access to information. This distinction is highlighted in the discussion of policy and agricultural development programs targeted toward emerging farmers.

\footnotetext{
Author Note

This study was completed in partial fulfillment of the lead author's master of science degree from the Department of Community Sustainability at Michigan State University.

\section{Funding Disclosure}

The research was supported in part by a Michigan State University Graduate Office Fellowship award.
} 


\section{Keywords}

Social Network Analysis, Incubator Farms, Local Food System, Entrepreneurship, Immigrant Farmers, Emerging Farmers, Agricultural Development

\section{Introduction}

Alternative food markets such as farmers markets and community-supported agriculture programs are increasing in number and scope across the United States, in part from a growing consumer awareness and demand for local food (Brown \& Miller, 2008; Hinrichs, 2000). Farmer decisions regarding which markets to sell their products often are driven by a number of economic, environmental, and demographic factors (Mishra, El-Osta, \& Shaik, 2010; Montri, Chung, \& Behe, 2021; Peterson, Barkley, Chacón-Cascante, \& Kastens, 2012). However, there are undoubtedly other cultural and social factors that farmers must consider, such as whom the farmer can ask for advice about selling their products. Interpersonal factors, sometimes represented in social networks, combine to influence farmer decision-making. These decisions are especially important to a farm's long-term success when the farm is small and is just starting (Calo \& De Master, 2016; Mailfert, 2007). This case study examines the structure and impacts of emerging farmers' social networks.

The proliferation of the local food movement in the American Midwest has been documented with great scrutiny (Bell, 2004; Hinrichs, 2003). The role of social connections in ensuring economic success among farmers has also been widely examined (Schiebel, 2005; Witt, 2004). What is more rarely studied is the relationship between specific social structures and the market access of farmers (Ashby et al., 2009; Mailfert, 2007). This case study focuses on market access by examining aspects of social connections and entrepreneurial success among emerging farmers. To do this, researchers studied farmer participants in a community organization that is classified as an incubator farm, meaning a nonprofit group that provides land, inputs, and training for individuals and families that wish to farm, but do not have the immediate ability to do so without assistance (Ewert, 2012; Niewolny \& Lillard, 2010). Incubator farm programs have gained prominence in the United States by providing training and assistance to young and beginning farmers (Ahearn, 2013; Katchova \& Ahearn, 2016). These programs are appealing because successful agricultural entrepreneurs often start out with minimal income and smaller-scale operations before becoming full-time financially viable farm operators (McGehee, 2007).

Emerging farmers face many barriers to success, as they often have limited access to land, credit, labor, technology, and capital (Ahearn, 2013; Ashby et al., 2009). Due to these challenges, local food and agriculture markets are often difficult for nascent farm enterprises to access (Flora, McIsaac, Gasteyer, \& Kroma, 2001; Thilmany McFadden et al., 2016). To overcome these challenges, farmers must hone their skills beyond just agricultural cultivation, they must cultivate a series of social relationships and establish a support system to achieve success (Hassanein, 1997; Poulsen, 2017; Schiebel, 2005). This case study, focusing on an incubator farm program in Michigan, is useful for considering the implications of the design and delivery of training programs and the implications of increasing market access for emerging farmers.

\section{Literature Review}

Social relationships can sometimes be seen as a form of capital, meaning a social resource with exchange-value inherent to its existence and application (Coleman, 1990; Portes, 1998). This social resource is anchored in the idea that benefits accrue to an individual as a result of the relationships in their social networks (Putnam, Leonardi, \& Nanetti, 1994). The aggregate of these social relationships can be analyzed by focusing on the resulting structure of their network (Marsden, 2002; Wasserman \& Faust, 1994). Social connections, or ties, can be made of different forms of relations, in terms of strength, typology, distance, and duration (Centola \& Macy, 2007; Lin, Ensel, \& Vaughn, 1981). Analysis can focus on a single actor (Giannella \& Fischer, 2016), a collective group (Marsden, 1990), or across multiple groups (Feld, 1981; Lorrain \& White, 1971). This leads to analysis of network actors and ties with respect to scrutinizing uniqueness, strength, and redundancy (Granovetter, 1973; Granovetter, 1974; Marsden, 
1990), or analysis of the precise structure of an entire network (Burt, 1995; Herz, Peters, \& Truschkat, 2014).

Scholarship focusing on social network analysis and entrepreneurship includes a rich body of work upon which to draw (Aldrich, 2005; Kuratko, 2016; Thornton, 1999). Targeted network characteristics have been demonstrated to both aid and hinder entrepreneurial success across several contexts (Smith-Doerr \& Powell, 2005 Swedberg, 2003). As an exemplar, possessing diverse ties in a business network has been demonstrated to increase access to information and provide new opportunities that aid entrepreneurs when they first start (Burt, 1993; Callon, 1998). Conversely, an entrepreneur's network with sparse connections and redundant relations has been demonstrated to constrain eventual success (Aldrich, 2005; SmithDoerr \& Powell, 2005). Another example showed that the nature of specific ties in a network are key when embedding an entrepreneurial venture in the market; these embedded ties are critical when trust and fine-grained information is needed (Uzzi, 1997). Other scholarship has presented a number of relationships between networks and entrepreneurial success. Among these relationships is the overall size of the network (Witt, 2004), the prevalence of strictly professional business relationships (Uzzi, 1997), and the overall diversity of actors and ties within a network (White, Boorman, \& Breiger, 1976). Using these network studies, scholars and practitioners have actively pursued strategies to improve network positions as a means of increasing the success of entrepreneurial enterprises (Kodithuwakku \& Rosa, 2002; Weber \& Kratzer, 2013). Given the diverse and comprehensive body of work dedicated to examining the role of social networks in the success or failure of nascent entrepreneurs (Government of Canada \& Policy Research Initiative, 2005; Witt, 2004), it stands to reason that the analytical approach represents a highly relevant and useful framework for examining emerging farmers in an incubator farm setting.

Social network analysis in agriculture has mostly been deployed in the examination of technology adoption (Bandiera \& Rasul, 2006; Spielman, Davis, Negash, \& Ayele, 2011). Much of this work is predicated on the importance of farmer-to-farmer networks, as well as the foundational principles of the Diffusion of Innovations (Rogers, 2003). While the theory has come under scrutiny in recent times (Stephenson, 2003), the consistent relevance to farmer-to-farmer information exchange networks serves to demonstrate the importance of close connections with farmer success, both commercially and productively (Christensen \& O'Sullivan, 2015; Hayden, Rocker, Phillips, Heins, Smith, \& Delate, 2018). Other scholars have demonstrated the limited efficacy of the farmer-to-farmer adoption model, with many positing that the cultural and ecological context is key in determining farmer adoption strategies (Knowler \& Bradshaw, 2007; Prokopy, Floress, Klotthor-Weinkauf, \& Baumgart-Getz, 2008). A thorough examination of an explicit type of network(s) is key in establishing the relevance of any case study focusing on farmers, agriculture, and market access.

Social networks have been shown to be key to entrepreneurial success by providing resource access, critical information, and risk management strategies for start-up farms (Hassanein, 1997; Mailfert, 2007). Over the longer term, networks have been demonstrated to be of paramount importance in accessing markets, providing social support, facilitating collaboration, and ensuring governmental support programs for vulnerable and entrepreneurial farms (Andreatta \& Wickliffe, 2002; Ashby et al., 2009; Christensen \& O'Sullivan, 2015; Hightower, Niewolny, \& Brennan, 2013). For example, one study demonstrated how women farmers in Pennsylvania were often excluded from the wider food system due to limited networks. The study stressed the importance of political agency among the farmers as a way in which to break down the exclusionary barriers that they face (Trauger, 2005). Other case studies arrive at similar conclusions, suggesting that networks were demonstrative of a gender disparity (Hassanein, 1997; McGregor \& Tweed, 2002). Other studies focusing on beginning farmers have noted the importance of social connections within immigrant communities in endowing market access (Hightower et al., 2013; Ostrom, Cha, \& Flores, 2010). Disparities in beginning farmer access to education, land, water, and capital have also been observed when examin- 
ing the social networks of immigrant farmers (Ostrom et al., 2010). One Midwest study indicated that small enterprises in local markets were heavily reliant upon key network actors and boundary spanners to ensure start-up success. The study identified that unmanaged nascent local food system entities, such as small farms, largely followed the trend of forming network ties through homophily and closeness affinity (Krebs \& Holley, 2006).

Boundary spanners are network actors which have a specific configuration of network ties that connect two relatively distant network groups. This actor is therefore often a key figure in providing access to the wider network among one, two, or more groups of network actors. They are often alternatively referred to as network hubs (Burt \& Merluzzi, 2014) or network weavers (Krebs \& Holley, 2006). Homophily is the concept of similar network actors commonly forming connections between one another due to the affinity of the sameness. Closeness affinity is prefaced on the idea that actors have a more favorable opinion of other actors who are located relatively near to them in their network. These foundational social network principles inform the examination of farmers' networks in this study.

Finally, many scholars have identified positive social interactions and interpersonal affinity to be key for farm success. The studies highlight the importance of building trust, social learning, and cooperative action through the creation of strong social bonds (DeLind, 2006; Hayden et al., 2018; Hightower et al., 2013; Jarosz, 2000). These contemporary examples serve to further demonstrate the nature of social connectedness as embedded within the American local food system (Christensen \& O’Sullivan, 2015; DeLind, 2006; Hinrichs, 2000).

\section{Applied Research Methods}

Many of the case study participants entered the incubator farm program with substantial agricultural experience. To acknowledge the variety of farming capabilities among the program, this study will use the term 'emerging' in place of 'beginning' farmers. A case study approach in this study was pursued by focusing on a targeted incubator farm setting, Lansing Roots, located in Lansing, Michigan. The Lansing Roots incubator program is training farmers and providing them with resources to begin their own farm business (Greater Lansing Food Bank, n.d.). Due to the stated goal of the program being to introduce new farmers into the local economy through active market strategies, the study was able to apply entrepreneurial network scholarship to this unique agricultural and sociological context. The program is "designed to help limited resource and/or historically under-served individuals from the greater Lansing area begin successful market gardening and farming enterprises through an incubator farm setting" (Greater Lansing Food Bank, n.d.).

The 11 farmers in the incubator program are defined as the case study sample. Although there were more than 11 farmers, the incubator program allotted 11 roughly equal sized plots for cultivation. Each plot was managed by an individual, couple, or family, and thus, sometimes more than one person is responsible for a single plot. Most plots had a single decision-maker. However, some plots had multiple decision-makers involved in the production, management, and selling decisions. For analytical clarity, the primary decision-maker and representative for each plot was determined to be the respondent farmer. Semistructured interviews utilized a self-reflection interview method to inquire about farmer perceptions and relations (Gist \& Mitchell, 1992). Interviews were conducted with individual farmers during the summer and fall of 2015. Eight interviews were conducted in English and three were conducted in Nepali with the help of a paid professional interpreter. The interviews were transcribed and coded thematically for analysis. A concurrent triangulation design for the utilization of both qualitative and quantitative methods ensured simultaneous data collection and analysis of interviews, ego-network analysis, and researcher field notations (Creswell, 2003; Creswell, Plano Clark, Gutmann, \& Hanson, 2003). The initial analysis examined farmer antecedents, meaning basic demographic information, stated aspirations, and initial access to resources. The final network analysis emphasized long-term outcome indicators derived from previous scholarship. The indicators included financial gains, skill develop- 
ment, quality of life, plans for the future, and personal efficacy as a successful market farmer (Ashby et al., 2009; Mailfert, 2007).

Network questions initially populated each farmer's personal networks' roster on a paper interview guide with the use of a free-recall method (Wasserman \& Faust, 1994). A free-recall method is an interview technique that allows respondents to name as many individuals as they feel are relevant to the question (Wasserman \& Faust, 1994). Network rosters then populated name interrelator matrixes to complete the personal networks of each farmer. This case study focuses on both the advice and support personal networks of farmers as unique ego-networks. An ego-network consists of a focal actor (also referred to as a focal node or ego) and the set of actors (also referred to as a node or alter) that are directly tied with the focal actor (Marsden, 2002). The advice question was, "Who do you discuss or seek advice from when marketing and selling your products?" The support question was, "Who do you celebrate selling and farming milestones with?" The interview also included a hypothetical network question, "Who do you think it is important to know for local farms to sell their products?" These questions were purposefully selected due to previous study findings that specifically highlight the importance of ego-networks in entrepreneurial and startup farm success (Ashby et al., 2009; Mailfert, 2007).

The interview protocol queried characteristics of network ties and alters. Among these characteristics are demographic information, the nature of ties, and the known alter connections. Tie strength is classified into four categories: family, friend, professional associate, and acquaintance. The strength of ties was analyzed quantitatively with a four representing a family tie, three a friend, two a professional associate, and one as an acquaintance. The analysis of the networks consisted of three main network categories of start-up and entrepreneurial success: (1) Networking activities; (2) Network structures; and (3) Network services (Government of Canada \& Policy Research Initiative, 2005; Witt, 2004).

Egocentric networks were selected for analysis to examine each farmer's network independently to fit into the case study approach. The selected measures included size (the total number of alters within a network), density (a value between zero and one, which measures the number of ties within a network as the numerator and the number of potential ties in a given network as the denominator), alter degree (the number of ties in which an alter possesses) (Marsden, 2002), diversity (the measure of the types of ties that an ego has access to) (Wasserman \& Faust, 1994), and tie strength (Government of Canada \& Policy Research Initiative, 2005; Witt, 2004). The strength of ties is measured both in the literal immediate and relative network-wide strength. Another way of interpreting tie strength is to consider the wider network context in which a particular alter is situated. This has been demonstrated in a wide range of network studies focusing on economic, employment, and entrepreneurial dynamics (Aldrich \& Zimmer, 1986). Under this conceptualization of tie strength, a weak tie is an asset because it represents an alter that is not redundantly related to the other ties within the ego's network. A strong tie is then an alter who is well connected with many redundant ties to alters that are already directly connected with the ego. The strength of weak ties theory indicates that these weaker ties provide access to new information and offer unique types of benefits that the ego would otherwise not be able to access (Granovetter, 1973; 1974). The final network examination took place in examining the benefits, costs, and other externalities that these networks provide. This allows for scrutiny of access to new information, the costs, and the benefits of personal networks.

\section{Findings}

\section{Farmer Information}

The 11 farmers and their families who were enrolled in the incubator program represented a diverse group (see Table 1). The genders of participating farmers were nearly equal, and their ages ranged from 22 to 70 years old. Farmers had varying levels of experience at the incubator farm, ranging from one to three years. However, this is not reflective of the farmers' total experience, with many farmers having been involved in agriculture since childhood. Farmer household incomes varied and every 
Table 1. Respondent Farmer Characteristics

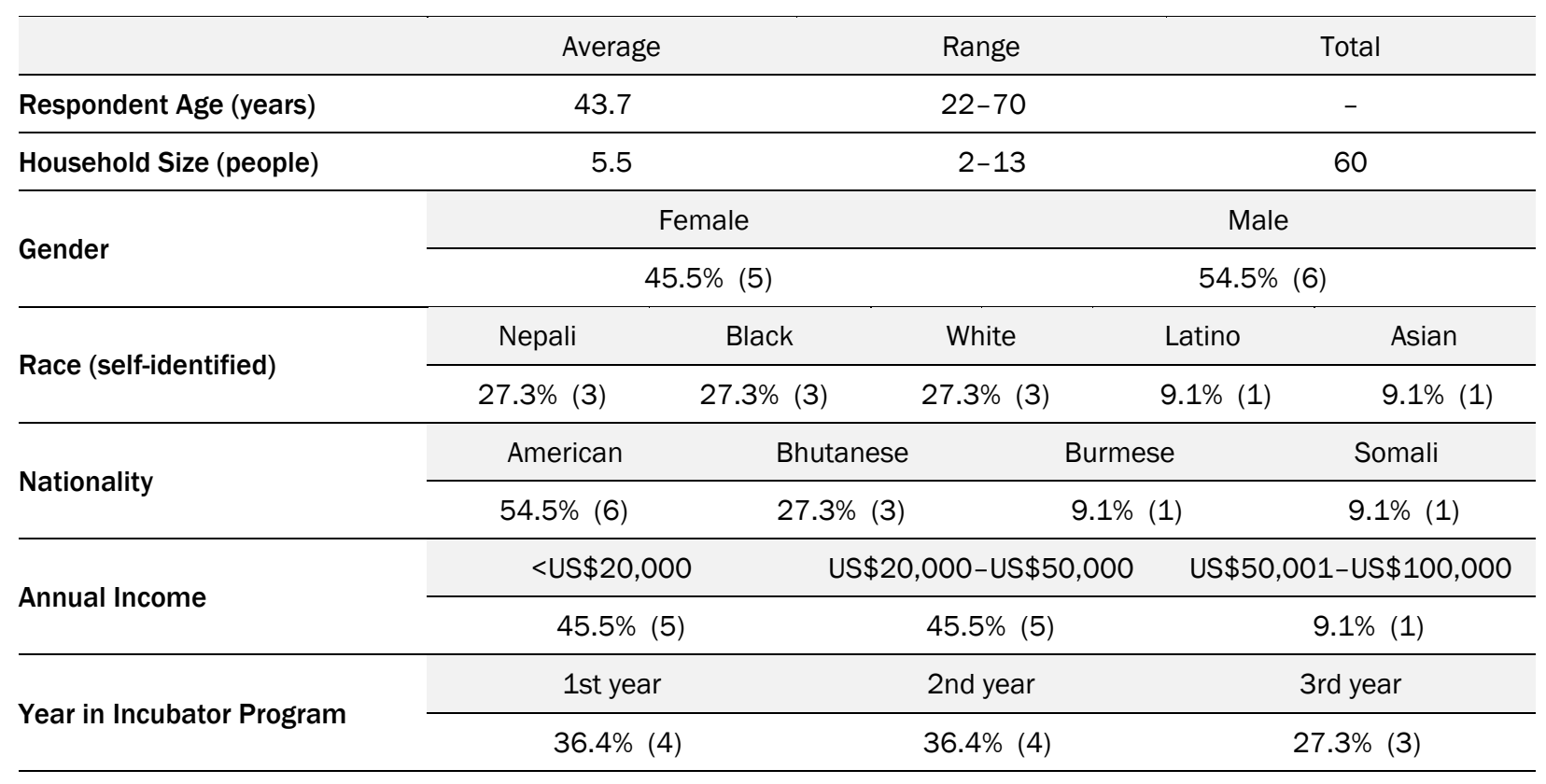

Note: Cell values display percentages unless otherwise noted. The number of responses is in parentheses. $N=11$.

household maintained income eligibility in the program. Household sizes ranged from two to 13. All farmers had at least one member of their household who provided income from non-farm sources. One farmer indicated they had full-time employment off the farm. Labor for farm plots was often provided by family members or close friends. Only two farmers were the sole laborers on their plots, and many indicated that it became a family event with their children to work on the farm. Farmers represented a variety of self-identified races and nationalities; with Lansing's substantial refugee population being reflected among participants. As one farmer stated of their children working on the farm, "They love coming out here."

Farmers focused on growing mostly vegetable products, although some cultivated ornamental and medicinal plants. Farmers reported that the incubator program was able to primarily support them in four ways. The first was providing the land on which to farm. The second was providing access to equipment (e.g., tractor) and inputs (e.g., compost). The third was providing technical assistance and regular educational opportunities to help farmers develop their production skills. Finally, the fourth indicated form of assistance was providing an outlet for the farmers to sell their products through one of two avenues. The occasional farmer produce stand or farmers market appearance was facilitated and staffed by Lansing Roots employees or volunteers. This was not the predominant form of selling assistance provided. The primary market opportunity provided by Roots was a very successful community supported agriculture (CSA) program. A CSA is a farm subscription service where community consumers make their payment at the beginning of a growing season in exchange for a set proportion of the farm's product (Brown \& Miller, 2008; Jarosz, 2011). The Roots CSA sold and delivered produce boxes every week to customers. The CSA provided an excellent outlet for the products the farmers had labored to grow. It also served as an exemplar in demonstrating to farmers how to forge successful market linkages with community members, local businesses, and nonprofit organizations that were all successfully enrolled in CSA membership.

\section{Aspirations and Barriers}

Entrepreneurial success, goal setting, and aspira- 
tions of success have been demonstrated to be closely related to one another (Jenssen, 1999). Farmers' motivations for joining the program and their plans for farming in the future varied between and within incubator program cohorts. The original motivation for farmers to enroll in the program ranged from wanting a hobby to launching a profitable vegetable production enterprise. These initial motivations for enrolling in the program played a large part in shaping farmer future aspirations. All of the American farmers discussed the valorous relationship between vegetable cultivation and the environment. They were heavily motivated to practice sustainable and agroecological farming practices. There is evidence that suggests that sustainable practices and gender are closely interrelated in the contemporary American farm landscape (Sachs, 1995; Sachs, Barbercheck, Brasier, Kiernan, \& Terman, 2016; Trauger, 2004). This was echoed by respondent farmers with all of the women expressing a desire to grow ethically sourced food. One female farmer said, "I see the local food movement as a necessary response to food insecurity and quality of food that [is] accessible to many people, low income, middle class, all populations, all groups of people.... It's sort of returning back to the original way of living and being, actually consuming food that was grown in close proximity to where you live. ... It makes economic sense, it makes health sense, it makes political sense, I mean it just makes sense from all standpoints."

Some farmers' identified aspirations to successfully or partially achieve self-sufficiency through their farm represented the successful obtainment of practicing an ethical form of farming. Among these farmers, a number referenced the idea of farming as physically and mentally restorative and an act of self-care. This ethic of moral farming idealism within alternative agriculture has been previously demonstrated to be a major motivating factor for many emerging farmers (Bell, 2004; Beus \& Dunlap, 1990; Jarosz, 2011; O'Hara \& Stagl, 2001; Wells \& Gradwell, 2001). Many farmers prioritized these moral ideals ahead of economic considerations. This meant that some farmers had limited, or even no engagement in local markets. However, the market aspirations and priorities among the farmers was shown to change over time and coincide with farmers' gradual introduction into local markets. This phenomenon has been expressly observed among emerging farmers as they increasingly become involved in the local food system through direct farmer-to-consumer market avenues (DeLind, 1999). One respondent stated, "We started with the mentality of, okay what do we want to grow for ourselves and that is why we are doing this primarily is just to learn how to grow our own food and then turned into, okay well what can we grow to contribute to the CSA, what can we grow hopefully maybe someday for a profit.... I think my aspiration for farming ... were to just grow as much food as I could that I could store to have clean food and to have food all year round that was food that I knew where it came from."

With the evolution of farmer aspirations and market efficacy, constraints on market access were identified as a major barrier to farmer success. The barriers that farmers faced were broadly classified into two categories: barriers to production (Figure 1) and barriers to market access (Figure 2). The farmers who discussed overcoming these barriers then demonstrated aspirations that were reflective of longer timetables. Conversely, farmers that did not discuss overcoming their production and market barriers demonstrated farming goals in more of a short-term context. All barriers were self-reported by farmers when answering openended questions.

The primary identified barrier to farm production was wetness and flooding. Part of this finding is simply a reflection of the weather during data collection. There was significant rainfall during the data collection period (i.e., June and July 2015) and many farm plots were not equipped to prevent water from collecting in its low points. Marginal clay soils were also identified by farmers as a driver of wet conditions on the plots. Exact locations of marginal soil were not demonstrated but standing water accumulation was observed in three to four low-lying points across the incubator fields. All of the farmers who had an impacted plot of land specified flooding as their primary production barrier. Other production barriers included pests and/or disease, weeds, off-farm commitments, language barriers, poor timing of planting and/or harvesting, and bad weather. The availability of labor was a common cause of many of the 
production barriers. Many farmers had limited availability to work on the farm due to other em- ployment or volunteer commitments. Other farmers lived too far from the farms' rural location and

\section{Figure 1. Farmer-Identified Production Barriers}

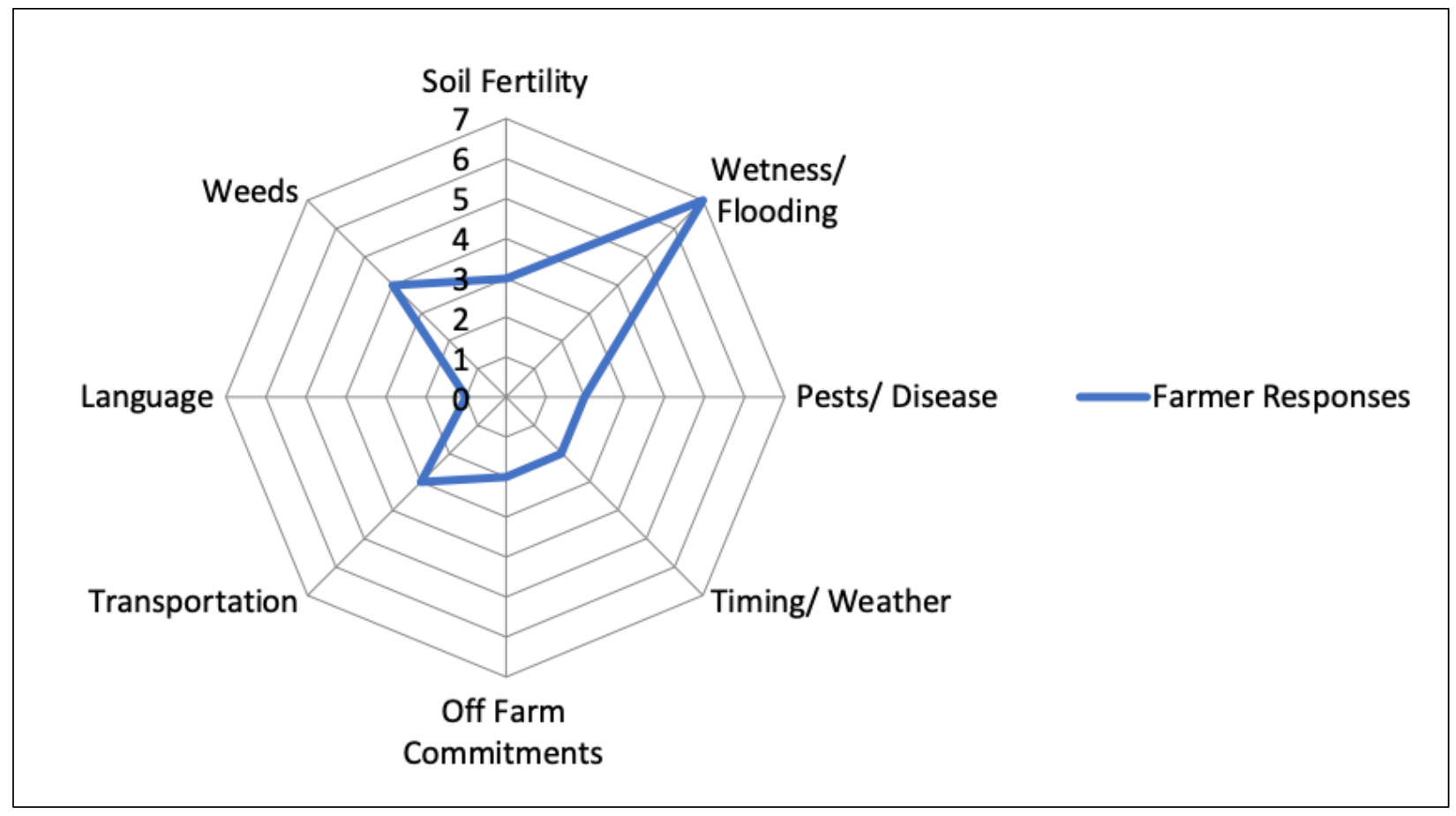

Source: Scott (2016).

\section{Figure 2. Farmer-Identified Selling Barriers}

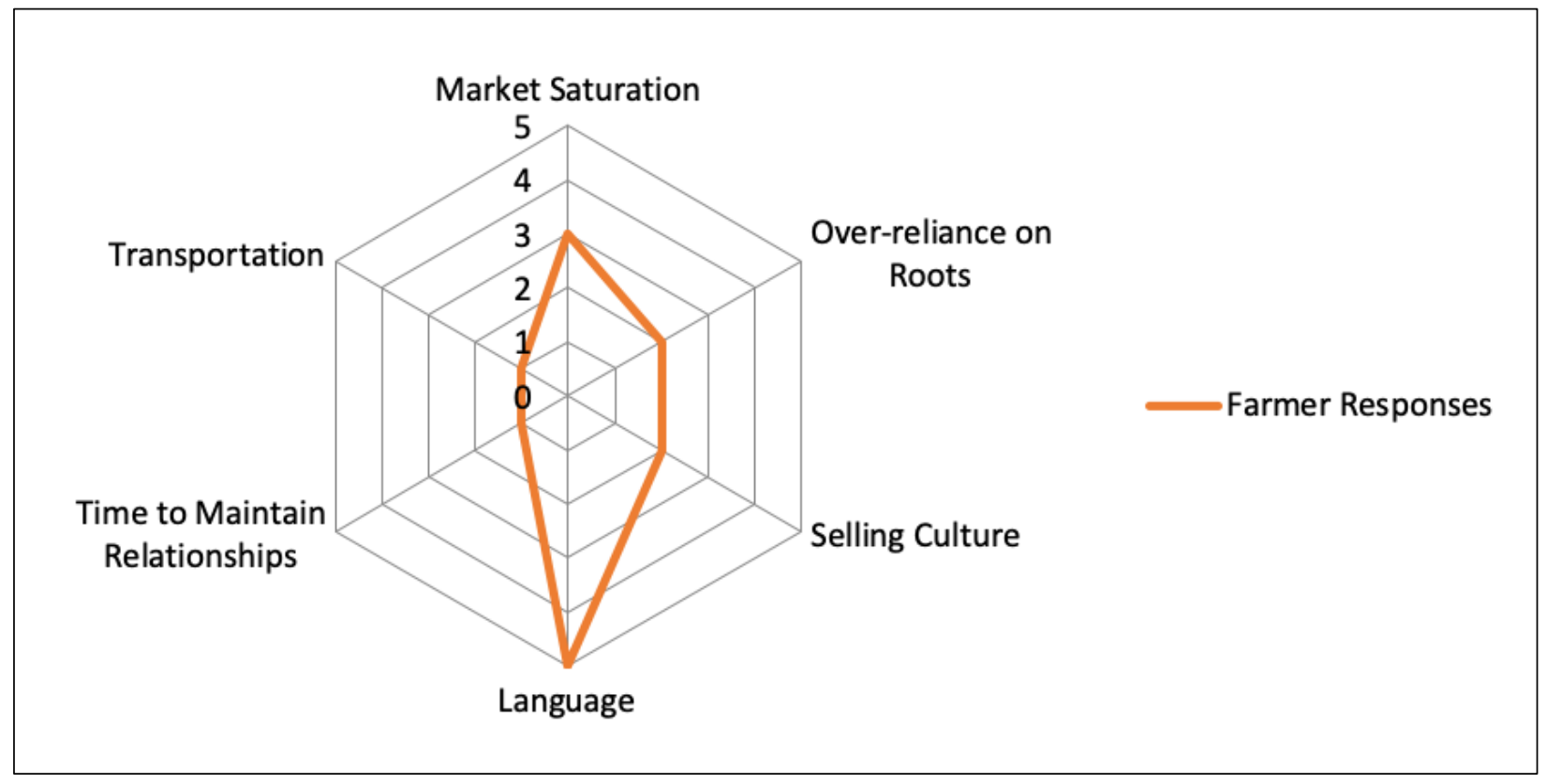

Source: Scott (2016). 
did not have access to a vehicle regularly. As a result of the distance, many farmers car-pooled to the incubator location to work on their farm. Sharing transportation occasionally puts constraints on times when the farmers were available to work. This meant that some time-sensitive tasks, like working to drain the fields after an extended rainfall, were not completed quickly enough.

The farmers also faced significant barriers to selling their products. In many cases, the selling barriers seemed to be proxy for the limitations for long-term success of the individual farms. While language was only explicitly indicated as a production barrier by one respondent, language was identified by many farmers as the primary selling barrier. Language as an obstacle for selling products was perhaps best exemplified by one respondent: "Due to [the] language problem, I don't know if I would be able to do it [sell products] because I don't know who wants what and I don't even know the names [of vegetables]. I can grow what they [the incubator program staff] provide me. I can do farming and I can grow plants but I don't know if I will be able to sell them." The language barrier was exclusively mentioned among immigrant farmers.

In addition to the language constraint, we can see demonstrated in Figure 2 that multiple farmers also indicated market saturation, the lack of a selling culture, and an over-reliance on the project staff as barriers to selling their products. The selfawareness demonstrated by the farmers in identifying these barriers is simultaneously encouraging and discouraging for the establishment of future autonomous entrepreneurial farms. The reflexivity demonstrated by farmers to acknowledge areas in which they need to improve to achieve financial autonomy is encouraging. However, as one farmer stated, "Ultimately, Roots is great, they do a lot of it [marketing and selling products], to the point that you don't have to hardly do anything to market it yourself. You just have to grow it and talk. to [Roots staff]. Which is a plus and a minus. In terms of not necessarily understanding how to go about it on your own." This respondent highlights the crux of the problem for the long-term entrepreneurial success of farmers once they graduate from the incubator program. While most farmers would not have been able to sell any products without the support of the program, many farmers chose not to pursue other selling avenues outside of the CSA. It is unclear whether other selling avenues even existed at all for farmers, or if farmers had any desire to pursue CSA alternatives, alternative market channels rather than CSA (like restaurant sales or farmers markets), or other CSA organizations.

Specific to entrepreneurial ambitions, three farmers indicated that simply selling all of their products constituted success in the program. Immigrant farmers noted that selling their products was not consistent with their cultural values as it relates to sharing food within their community, where food is freely shared between households without any expectation of reciprocation. The barriers to both selling and cultivating played unique roles in shaping self-identified farmer success. The definitions of success included achieving food selfsufficiency, achieving farm profitably, transitioning to farming as a career, making time for recreation, and farming to learn about cultivation. These ambitions speak to the reality that many farmers do not think that entrepreneurial success is obtainable, and perhaps more significantly, many farmers possess no or very little desire to achieve entrepreneurial success through farming.

\section{Networking Activities}

Farmers built and maintained networks through interacting with other farmers, attending conferences, and seeking the council of Roots staff. One farmer indicated time as a constraint in forming interpersonal farm interactions, leading to a barrier to selling farm products. Farmers spent between 0 and 15 hours a week networking. Networking strategies included attending conferences, potluck dinners, and farmers markets to meet local food system actors. Most indicated that a maximum of two hours a week were dedicated specifically to networking. While the time spent networking and the specific strategies did not seem to have an impact on the size of networks, there was an indication that networking activities did have an impact on advice network composition. If a farmer identified a strategy for networking, regardless of time, their advice networks extended beyond the incubator program staff. Conversely, if no strategy was identified, advice networks did not extend 
beyond the incubator program staff. It is unclear whether the act of networking, or the reflexivity demonstrated by having a networking strategy, was causally related to the size of the farmers' advice networks.

\section{Advice Networks}

Advice networks mapped who respondents indicated they reach out to when marketing and selling their products. Farmer advice networks ranged in size from 2 to 16 individuals.

Quantitative advice network characteristics can be seen below in Table 2. In total, the average advice network density was 0.74 . The average size was 4.73 people. Tie strength for all 3 measures (ego, total, and alter) was slightly above $2(2.23,2.18$, and 2.09), indicating that professional associations dominated the advice networks. The average alter degree was 2.10, meaning that the average advice network alter knew a little more than 2 other members of the network. The effective size of networks ranged from 1 to 9.44 with an average of 2.63, representing networks with a small amount of diversity (1) and networks with a high amount of diversity (9.44).

From the examination of farmer advice networks, two classifications of networks emerge with one group having a density of 1 and another group with a density of less than 1 . Network density is a statistic that identifies the amount in which network alters know the other alters within the network (Giannella \& Fischer, 2016; Marsden, 2002). In the formula seen below $D$ represents density, $N$ represents the number of nodes within a network, $\lambda$ represents ties within a network, and $N(N-\lambda) / 2$ represents all of the possible ties within a network.

$$
D=\overline{N(N \quad) / 2}
$$

The density of one means that the networks have an effective size of 1.00, the highest possible value for the statistic. Effective size is a statistic that represents the diversity of information sources within a given network. The measure indicates the amount of redundancy among the alters in a network (Burt, 1995). The statistic is calculated by subtracting the average alter degree from the total number of alters (network size) (Borgatti, Everett, \& Johnson, 2013).

All 5 advice networks with a density of 1 exclusively consisted of the incubator program staff. Figure 3 provides the sociogram representation of this most common advice network. These networks, therefore, shared a commonality in the strength of the relationship (professional association), the length of time the alter has known the farmer (the amount of time the farmer has been

Table 2. Advice Network Statistics

\begin{tabular}{cccccccc}
\hline Farmer & Density & Size & $\begin{array}{c}\text { Ego average tie } \\
\text { strength } \\
\text { (E-ATS) }\end{array}$ & $\begin{array}{c}\text { Total network } \\
\text { average tie strength } \\
\text { (T-ATS) }\end{array}$ & $\begin{array}{c}\text { Alter average tie } \\
\text { strength } \\
\text { (A-ATS) }\end{array}$ & $\begin{array}{c}\text { Average alter } \\
\text { density } \\
\text { (AAD) }\end{array}$ & Effective size \\
\hline 1 & 0.17 & 4 & 2.25 & 2.20 & 2.00 & 0.50 & 3.50 \\
2 & 0.52 & 7 & 2.71 & 2.44 & 2.27 & 3.14 & 3.86 \\
3 & 1.00 & 2 & 2.00 & 2.00 & 2.00 & 1.00 & 1.00 \\
4 & 1.00 & 2 & 2.00 & 2.00 & 2.00 & 1.00 & 1.00 \\
5 & 0.43 & 16 & 2.22 & 2.04 & 2.02 & 6.56 & 9.44 \\
6 & 0.89 & 8 & 2.22 & 2.03 & 2.00 & 5.37 & 2.63 \\
7 & 1.00 & 2 & 2.00 & 2.00 & 2.00 & 1.00 & 1.00 \\
8 & 0.17 & 4 & 2.50 & 2.40 & 2.00 & 0.50 & 3.50 \\
9 & 1.00 & 2 & 2.00 & 2.00 & 2.00 & 1.00 & 1.00 \\
10 & 1.00 & 3 & 2.33 & 2.50 & 2.67 & 2.00 & 1.00 \\
11 & 1.00 & 2 & 2.50 & 2.33 & 2.00 & 2.00 & 1.00 \\
\hline Average & 0.74 & 4.73 & 2.23 & 2.18 & 2.09 & 2.10 & 2.63 \\
\hline
\end{tabular}




\section{Figure 3. High Density Farmer Advice Network (the Most Common Advice Network Structure)}

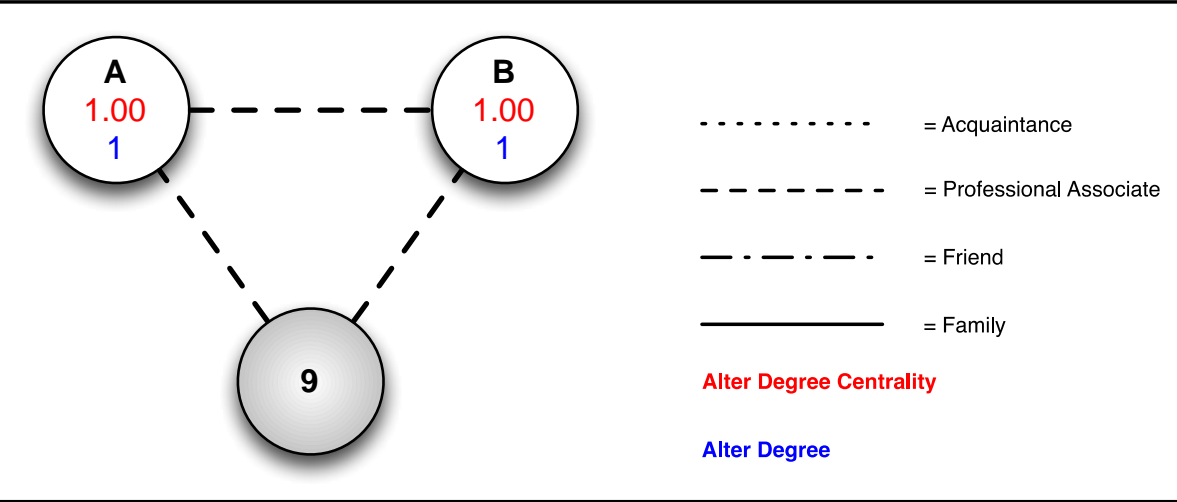

Source: Scott (2016).

Figure 4. Diverse Farmer Advice Network (Made Up of All Four Types of Ties)

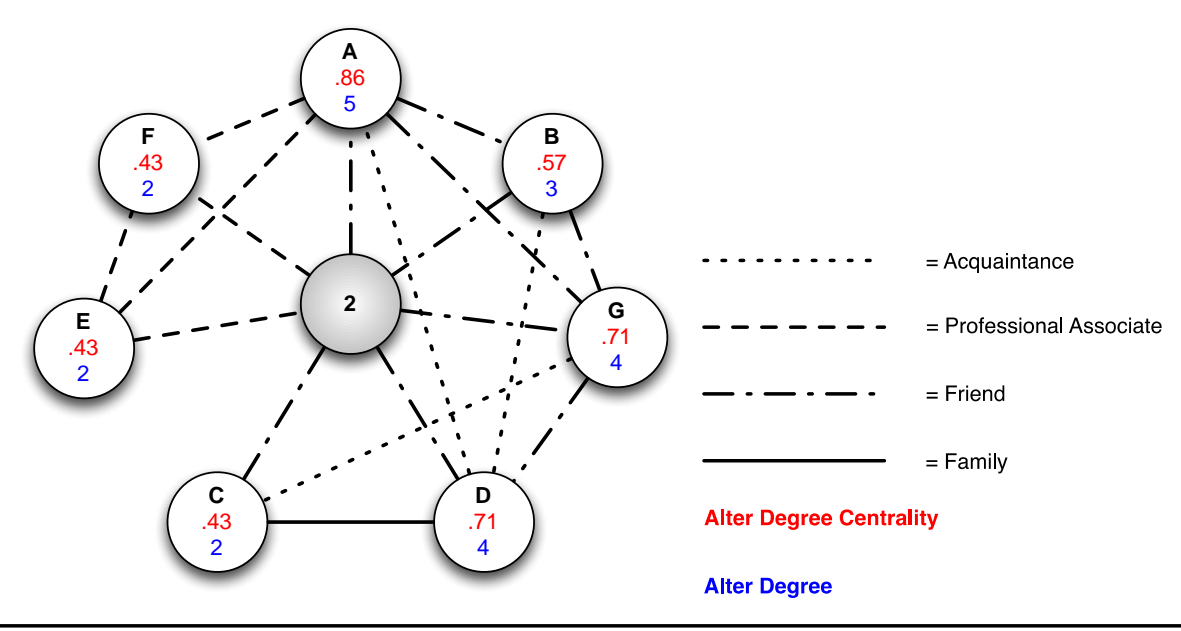

Source: Scott (2016).

involved in the incubator program), and are racially and nationally homogenous (white Americans). All of these farmers with limited networks were immigrants. In contrast, 5 farmer advice networks demonstrated a lower density and more variation in overall size, alter types, and tie characteristics. These networks ranged in size from 4 to 16 with densities between 0.17 and 0.89 . The average tie strength was higher among these networks in all three classifications (ego, alter, and total tie strength). Average alter degree ranged from 0.50 to 6.56 and network effective size ranged from 2.63 to 9.44. The classification of these two types of advice networks can be summarized by saying that the non-immigrant farmer advice networks were less dense, larger, consisted of stronger ties, were more diverse (in all alter characteristics besides gender), and had less tie redundancy (due to higher effective sizes) than the comparable immigrant advice networks that consisted exclusively of incubator program staff members.

Comparing all 11 farmers, the differences between the farmers with more expansive advice networks and farmers with more limited advice networks provide a stark contrast that enables comparative analysis between them. Farmers with a more limited network were younger (average age of 37.8 compared to 51.2), involved in the program for longer (2.2 years compared to 1.7 years), had larger household sizes (average of 7.6 compared to 3.7), and were mostly minority females. In contrast, the more expansive networks were mostly comprised of white older male farmers with less time in the incubator program and smaller households. An exemplar of a more diverse advice network can be seen below in Figure 4.

Farmers were asked what the hypothetical ideal advice network would look like. The ideal advice network characteristics of possible alters consisted of predominantly professional associations. These roles included a local chamber of commerce representative, restaurateurs, community members, farmers market managers, wholesalers, farmers, customers, and members of food cooperatives. 
Farmers indicated that the ideal advice network would include many social and economic connections with the wider local food economy outside of the farm.

\section{Support Networks}

Support networks mapped who respondents indicated they celebrate marketing and selling milestones with. Farmer support networks were found to be more diverse in their composition and larger than the advice networks. The average density was similar to advice networks with a value of 0.75 , as shown in Table 3.

Support network size ranged from 3 to 32 with an average of 13.36. Tie strength for all measures (ego, total, and alter) is greater than that of the advice networks (3.27, 3.19, and 3.02). The higher tie strength is reflective of increased familial and friendly interpersonal relationships. Average alter degree of 10.25 demonstrates the interconnectedness of support alters. An effective size of 3.20 is higher than that of the advice networks but not nearly to the amount that is commensurate with the increase in overall network size. This indicates a relatively high amount of redundancy within the support networks. These trends can be observed in Table 3. An exemplar support network can be seen in Figure 5.

Social support is considered as a key element of entrepreneurial success (Swedberg, 2000; Witt, 2004). Support networks measured the number of individuals that a farmer listed as people they celebrate farming milestones with. Support networks demonstrated a high amount of homophily, meaning alters were found to be more racially homogenous and more reflective of the farmer respondent's racial make-up. Many networks were very large, as seen in Figure 5. Larger networks belonged primarily to immigrant farmers while farmers that have engaged in the local food economy before their involvement indicated smaller networks. Immigrant farmer support networks were mostly made up of family ties. Non-immigrant farmers were more likely to indicate professional and friendly ties within their support network.

\section{Network Costs and Benefits}

Both networks demonstrate a distinct set of costs and benefits. Support networks offered respondents with enhanced emotional and physical endurance. Many farmers rely on members of their support network to help them on the farm during particularly busy times. No farmer indicated a substantial cost that is derived from support networks. However, some immigrant farmers discussed a form of altruism as their role in this network, meaning that they felt culturally obligated to share the food they produced across their support

Table 3. Support Network Statistics

\begin{tabular}{cccccccc}
\hline Farmer & Density & Size & $\begin{array}{c}\text { Ego average tie } \\
\text { strength } \\
\text { (E-ATS) }\end{array}$ & $\begin{array}{c}\text { Total network } \\
\text { average tie strength } \\
\text { (T-ATS) }\end{array}$ & $\begin{array}{c}\text { Alter average tie } \\
\text { strength } \\
\text { (A-ATS) }\end{array}$ & $\begin{array}{c}\text { Average alter density } \\
\text { (AAD) }\end{array}$ & Effective size \\
\hline 1 & 0.30 & 5 & 2.60 & 2.13 & 1.33 & 2.20 & 3.80 \\
2 & 0.52 & 19 & 3.63 & 3.88 & 3.54 & 9.47 & 9.53 \\
3 & 1 & 21 & 3.05 & 3.00 & 3.00 & 20.00 & 1.00 \\
4 & 1 & 26 & 4.00 & 4.00 & 4.00 & 25.00 & 1.00 \\
5 & 0.60 & 5 & 3.00 & 2.82 & 2.67 & 2.40 & 2.60 \\
6 & 0.62 & 15 & 3.27 & 2.74 & 2.84 & 3.67 & 6.33 \\
7 & 0.60 & 5 & 3.40 & 3.55 & 3.17 & 2.40 & 2.60 \\
8 & 0.71 & 8 & 3.25 & 3.36 & 3.45 & 3.00 & 3.00 \\
9 & 1 & 8 & 3.50 & 3.19 & 3.11 & 2.00 & 1.00 \\
10 & 1 & 3 & 2.33 & 2.50 & 2.67 & 3.00 & 1.00 \\
11 & 0.92 & 32 & 3.91 & 3.94 & 3.94 & 28.62 & 3.38 \\
\hline Average & 0.75 & 13.36 & 3.27 & 3.02 & 3.25 & 3.20 \\
\hline
\end{tabular}




\section{Figure 5. Farmer's Support Network}

Displayed is an extensive support network structure with a large number of ties relative to other farmer support networks.

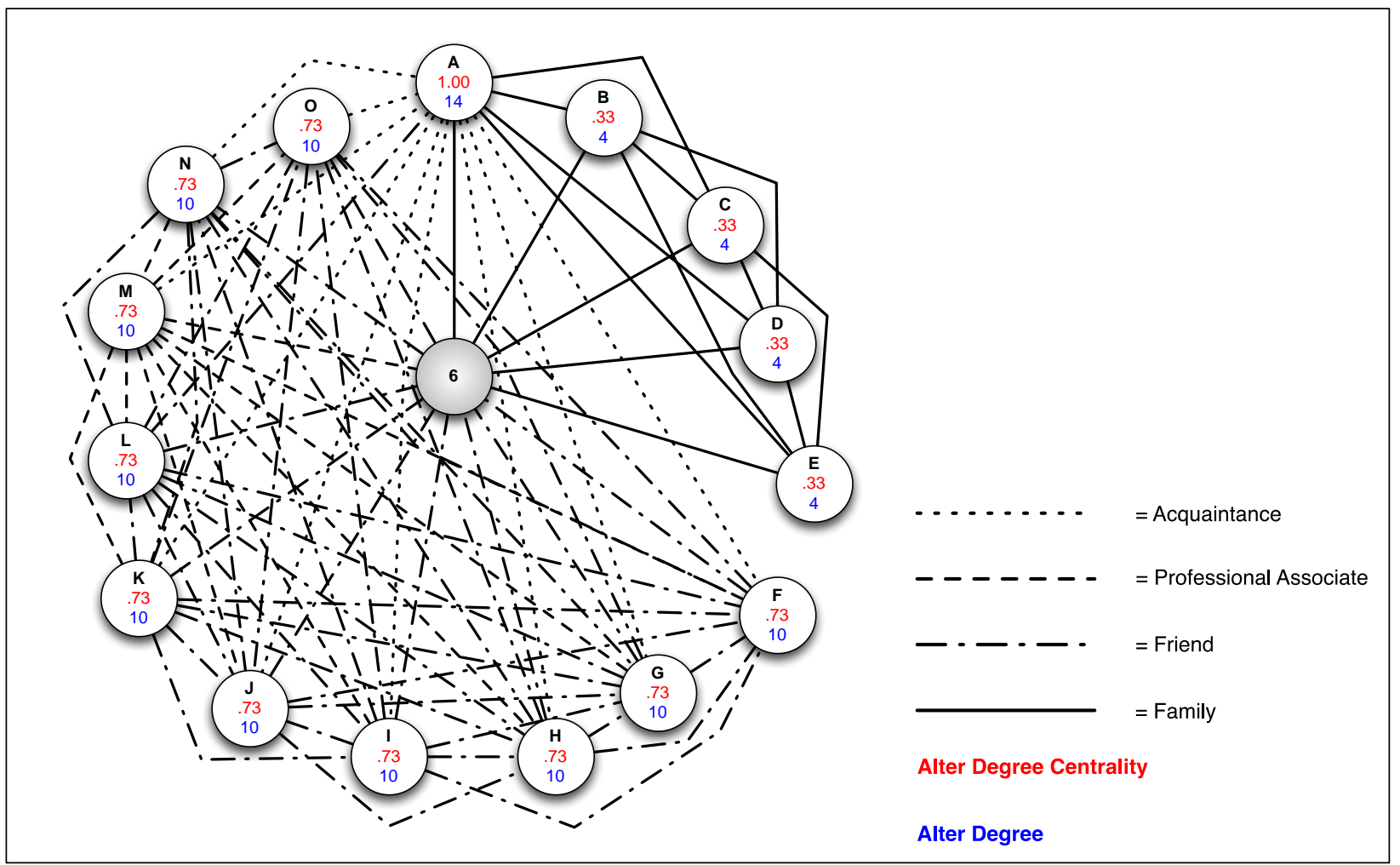

Source: Scott (2016).

network. This was not discussed as a negative practice by farmers, but the food provided was not reciprocated financially.

Advice networks were largely bereft of financial costs to farmers. One farmer did mention the $20 \%$ that the incubator program takes from market sales as a potential cost. Although, the fee was widely considered by the farmers to be a necessary cost to ensure the program's financial sustainability. Most farmers indicated that the main cost of building and maintaining their advice network was time and effort. The primary benefit derived from the advice networks was enhanced farming and marketing knowledge. This benefit did directly address the farming and selling barriers that farmers had previously identified.

As one farmer stated, "The main benefits for me this year is my skill that I learn. And the second is the money that I make and the third is the food I am enjoying." With this short statement, the farmer discusses the three main benefits that the advice networks provided: food for consumption, money from product sales, and enhanced farming skills. Farmers sold between $50 \%$ and $100 \%$ of the products they cultivated, with an average of $77.42 \%$. All but one farmer indicated they consume or give-away between $5 \%$ and $40 \%$, with an average of $22.58 \%$ of products being consumed or gifted by the farmer and their household. The incubator program affords access to the advice networks that farmers need to begin a successful entrepreneurial business. One farmer stated about the skills they obtain from the incubator program staff and other advice network members, "How to farm, how to not [farm], what works, what doesn't. How to find information. ... Pricing, what the market [is], yeah all that stuff. Presentation, legal issues, I mean there is certainly a lot of food safety issues. I mean just generally, general information about the industry [local food system] standards."

These direct network benefits lead to enhanced market access by farmers and situate their nascent farms within the local food economy. Improved 
self-efficacy after engaging with advice network member(s) was observed. One farmer stated, "I mean, we were not farmers when we started [the incubator program]. Now I'll say, yeab I'm a farmer." However, this enhanced sense of farming ability and identity did not automatically translate into farmers' indicating plans to make the farm financially viable in the long-term. Only two farmers indicated plans to continue farming with the vision of establishing an autonomous farm business.

Farmer ambitions for a long-term entrepreneurial farm operation demonstrated a similar dichotomous theme to that of the advice network composition. Immigrant farmers indicated barriers to establishing more diverse and enriching advice networks, as discussed earlier, due to substantial language barriers. "If I spoke English I would do better than this. I would talk to them [customers and advice-givers] but these days I cannot understand so I [don't] know the names of the vegetables that I plant now." This farmer provides one example of how the language barrier creates an asymmetrical perception of success between immigrant and non-immigrant emerging farmers. While immigrant farmers demonstrated low levels of entrepreneurial self-efficacy, many non-immigrant farmers indicated that they felt they could, if they wanted to, pursue a financially successful farm. When asked about the ability of other emerging farmers, respondents indicated they believed that others had sufficient market access, seemed happy, and are or will be able to successfully sell all of their products. Despite many farmers' negative perceptions of their own ability to practice market-oriented agriculture, it is important to note that they considered the other emerging farmers to be successful.

\section{Discussion}

Despite being in the program longer, the younger minority female farmers had more limited advice networks compared to other farmers. This disparity was evident in the density and effective size of their advice networks. The average increase in density for the network that extends beyond the incubator staff was 0.40 . The more expansive networks had an average of 5 more alters, mostly professional ties. The increase in network size and the decrease in network density for the more expansive advice networks led to an increase in effective size (on average 3.41 larger). This is a sign that there is less redundancy, and therefore more diversity in the type of advice they receive. The novelty of the advice is consistent with the strength of weak ties theory, which posits that it is advantageous for the network ego to have social ties with more socially distinct alters (Granovetter, 1973). The theory is exemplified within this case study because the more expansive networks have less redundancy of advice and exhibit more advantageous indicators of market access. This improved market access then coincides with greater entrepreneurial efficacy among farmers.

Advice networks within this case study observed gender, linguistic, and nationality disparities. Other studies have additionally documented gender disparities in market access among women entrepreneurs (Greene, Brush, \& Gatewood, 2007; Schwartz, 1976). A lack of economically enriching social ties has been documented as one of the major barriers to success for entrepreneurial women across many economic sectors (Fairlie \& Robb, 2009; Minniti, 2009). When an entrepreneur's social connections do not include individuals who either have access to capital, or do not have relationships with others that have access to capital, their access to start-up capital is constrained and their long-term success often suffers (Fairlie \& Robb, 2009; Kodithuwakku \& Rosa, 2002).

Women farmers face a unique set of challenges and opportunities when they decide to become farmers (Chiappe \& Flora, 1998; Liepins, 1998). Often the act of farming is an expression of gendered relationships between the farmer and the land in which they cultivate (Brasier, Sachs, Kiernan, Trauger, \& Barbercheck, 2014; Sachs, 1995; Trauger, 2004). Women farmers have been demonstrated to have social networks that are more reflective of socioeconomic and environmental justice, as opposed to profit maximization (Sachs et al., 2016; Trauger, 2005). Women and their social connections have been found to be the backbone of CSAs and local food movements in the United States (Allen \& Sachs, 2007; Wells \& Gradwell, 2001).

Given that time and effort is an identified cost of advice networks, it is therefore an area in which policy and programs can aid in saving farmers time 
as they strive to efficiently labor on their farms and cultivate social networks. Examples of these types of initiative programs, which can help reduce gender disparities in sustainable agriculture, are evident in the Pennsylvania Women's Agricultural Network which has achieved a good deal of success. The network "supports women in agriculture by providing positive learning environments, networking, and empowering opportunities" (The Pennsylvania State University, n.d.). These kinds of initiative programs are good examples of bringing together elements of human and social capital to enhance emerging farmers' networks (Trauger, 2005).

The advice network disparity in many ways mirrors an overall American societal socioeconomic inequity that is faced by minorities in the food system (Alkon \& Agyeman, 2011; Flora, Emery, Thompson, Prado-Meza, \& Flora, 2012; Morland \& Wing, 2007). Network disparities also mirror wider inequities that lead to the socioeconomic isolation and increased health vulnerability among immigrant and refugee populations (Fennelly, 2004; Morris, Popper, Rodwell, Brodine, \& Brouwer, 2009). Immigrant famers were shown to have more limited advice networks when compared to non-immigrant farmers. This distinction held true for both immigrant farmers that spoke English and for the immigrant farmers that did not speak English. While the reasons for the constraints among the non-English speaking farmers were explicitly stated, the reason for limited advice networks among English-speaking immigrant farmers was less obvious. Language as a barrier was the mechanism that limited refugee farmers from expanding their advice networks beyond the incubator program staff. This was consistent with the wider selling barriers identified by farmers as they most commonly stated language as the primary barrier. Similarly, two other identified selling barriers, an over-reliance on Roots program staff to market products and an aversion to a selling culture, offer insights into why English-speaking immigrants also have limited advice networks. These selling barriers are consistent with previous scholarship focusing on incubator farm programs and immigrant and refugee populations (Hightower et al., 2013; Ostrom et al., 2010; Panopoulos, 2013).
Language as a barrier did not appear to adversely influence the production of farm crops. Instead, the primary production challenges faced by farmers had more to do with the environment and natural conditions. Throughout the interview time periods, there were concerns about flooding and poor drainage. This speaks to the effectiveness of the interpersonal programming that facilitated largely successful crop production by emerging farmers and also highlights the environmental challenges that many farmers face.

In addition to praising the incubator program for increasing their cultivation skills, farmers also indicated the program's market outlets as a highly desirable program outcome. The primary identified advice network benefits could also be seen as synonymous with the perceived incubator program benefits for farmers. The benefits broadly fall into three classifications:

\section{(1) Healthy and affordable food for} consumption among farmer households. Many farmers indicate that the food which they produced played an important role in their household's food security status. Other farmers discussed the products as being supplementary in their seasonal diets and helped them to achieve a healthier lifestyle. Immigrant and non-immigrant farmers alike indicated that they use the produce as gifts to friends, family, and community members as a way to spread goodwill and healthy food.

(2) Many of the farmers indicated that their farming skills had been greatly improved through their involvement in the program. Prideful accounts about new planting techniques, the use of new farm tools, and other farming skills were common throughout the interviews. Many farmers discussed the personal satisfaction they and their households received by being involved in agriculture. This satisfaction also tied into intergenerational agricultural heritage when farmers indicated they felt it was a way to connect with their elder family members or involve their children with the farm. Refugees discussed their participation as a way to maintain their cultural ties with agriculture and the environment in a way that was previously not possible. 
(3) Many farmers discussed the incubator program as economically empowering. Lowerincome farmers highlighted the usefulness of the money and market opportunities that they receive from CSA and farm stand sales. Farmers of all income levels reacted positively when queried about sales, citing the funds as useful in increasing supplementary income for their households. It is here that the incubator program encounters a double-edged sword in their marketing endeavors.

While the CSA and other market opportunities make it possible for farmers to financially benefit from their labor, some farmers, both immigrant and non-immigrant, indicated that they were not engaged in advice networks and market relations because the program staff (the CSA program) did it for them. This dynamic is further complicated when examining the role that the established program market avenues play among immigrant and refugee farmers. All of the farmers indicated that they were engaged in the CSA. Some immigrant farmers discussed being reluctant to sell their products within their community because they had a tradition of freely giving food amongst their friends, family, and community members. The most common and most heavily emphasized barrier for market access was language. The effects of this barrier manifest itself within immigrant farmer advice networks. The lack of key non-program professional associations that provide advice about market opportunities means that the long-term entrepreneurial efficacy of immigrant farmers is, ultimately, very low. The program's CSA offers farmers immediate short-term benefits: money from sales and the experience of participating in the market opportunity. Farmers are able to advance their skills in growing, processing, and packaging their products for sale. The program's CSA provides a critical return on investment for the time and effort that farmers put into their plot. At the same time, farmers are not gaining experience in recruiting and retaining CSA members or finding their own market opportunities. The Lansing Roots mission is to help reduce the barriers that farmers face in becoming successful farm enterprises (Greater Lansing Food Bank, n.d.). This study provides mixed evidence regarding the fulfillment of this mission in that the program endows farmers with a wealth of production knowledge and yet there appears to be missing elements of the incubator program curriculum that enhance farmer skills when accessing local markets. This limitation is not unique to Lansing Roots, with many incubator farms experiencing difficulties due to language and cultural differences in balancing fiscal rewards with the facilitation of farmer networks for sustainable market access (Panopoulos, 2013). Language and cultural barriers are often cited as the primary barrier to economic self-sufficiency among refugee populations (Halpern, 2008). Limited access to advice networks by the farmers in this study demonstrates the need for incubator programs to facilitate the creation and maintenance of networking opportunities and to integrate them into their programming.

Other scholars have noted the hegemonic paradigm of privileged exclusiveness (whiteness) against minorities in the local food systems of the contemporary American Midwest (Calo, 2020; Flora et al., 2012). It is recommended that increased critical social science research be conducted with a focus on minority and refugee farmers as nascent entrepreneurs. It is also recommended that increased attention be focused on providing refugee populations with language services to assist them in forging the types of social and economic relationships that will enable them to have successful autonomous and profitable farm ventures in the future. Successful programs such as the Refugee Agricultural Partnership Program (U.S. Department of Health \& Human Services, 2012) can be looked to as an example of programs with such a focus. It is additionally recommended to expand such programs to assist incubator farms in effectively achieving their aims regarding refugee farmers and successful agricultural entrepreneurship. Other incubator programs have had success in advancing immigrant and refugee farmers market capabilities by pursuing farmer-to-farmer education, mentoring, and demonstration farming (Ostrom et al., 2010; Rhodes \& Joseph, 2004).

While network redundancy is not a positive sign within advice networks, the same cannot be said regarding entrepreneurial support networks (Dubini \& Aldrich, 1991), especially among 
emerging farmers (Mailfert, 2007). The benefits derived from larger support networks represent a form of social enhancement that embolden any potential farmer to engage with the incubator program. In contrast with advice networks, immigrant and refugee farmers exhibited larger, denser, and more strongly related (mostly familial in nature) support networks. These networks are likely formed because of a shared language or cultural closeness within their community and they provide a reason for optimism as the farmers move forward and strive to find a niche within the local Mid-Michigan food system. This provides reason for optimism because many immigrant communities foster entrepreneurship and business development due to their close-knit social networks providing an 'ethic enclave' economy (Wilson \& Martin, 1982; Wilson \& Portes, 1980). While immigrant entrepreneurs often have limited access to outside networks (Li, 2004), they often obtain access to markets and sources of credit from their own insular immigrant networks due to linguistic and cultural similarities (Sanders \& Nee, 1996). Because of this, for many immigrant entrepreneurs, family relationships prove to be important in determining their eventual business success (Sanders \& Nee, 1996; Waldinger, Aldrich, \& Ward, 1990). Of relevance to this study, abundant family ties have been demonstrated to be highly advantageous for immigrant farmers (Bloom \& Riemer, 1949), with immigrant farmers often experiencing success in farming and selling within their own immigrant communities (Brown, 2011; Hightower et al., 2013). Often immigrants and refugees are drawn to farming because they may have come from agricultural backgrounds (Macy, 2019). Incubator farm programs have been demonstrated to be effective in providing benefits to nascent immigrant farmers (Laverentz \& Krotz, 2012). However, despite the prominence of these programs, there is a lack of research that examines their impact on immigrant farmers (Hightower et al., 2013; Ostrom et al., 2010). This research parallels some of the findings from these studies, such as recommending that language services be emphasized to enhance market access, as well as echoes these calls for more research (Hightower et al., 2013; Ostrom et al., 2010).
While support networks present evidence to support the long-term entrepreneurial efficacy of immigrant farmers, advice networks indicate that, for many farmers, their ability to continue as successful market farmers after they depart from the incubator farm setting is ultimately unlikely. Limited advice networks were also demonstrated among women and immigrant farmers. Limited advice networks were networks that were limited to only staff members of the incubator farm program, implying that the farmer did not seek out advice regarding selling or marketing their products from anyone outside of the program. A number of farmers did not speak English and, while this was identified as the primary selling barrier among farmers, a number of farmers who spoke English also indicated a constrained advice network. Further research is needed to explore the reasons why disparities exist between farmers' advice networks, how these disparities can be addressed in an incubator farm program curriculum, and what, if any, the consequences are of these disparities on the eventual long-term entrepreneurial success of farmers.

\section{Conclusion}

This study is highly relevant today, given the expansion of farmer training programs and farmer support programs, an increasing refugee population, and an increasing population of emerging farmers. This case study has implications for the design and delivery of training programs and for increasing market access for emerging farmers. A clear delineation is found within this case study between farmers with diverse advice networks and farmers with more limited networks. The advice network disparity resulted in disadvantageous longterm entrepreneurial indicators for women, nonEnglish speaking, and minority farmers. Support networks were decidedly larger and consisted of stronger ties, both in their nature (familial) and in their structure (highly dense), among immigrant farmers. The most prominent barrier to farmers market access and expanding advice networks beyond the incubator program staff was a language barrier. This resulted in farmers having a degree of economic dependency on the program to sell their crops, which underscores the importance of access 
to markets. On the other hand, the incubator program's established CSA was highly effective in engaging emerging farmers in cultivation for market sales through building farmer knowledge of planning, planting, harvesting, packing, and marketing for direct customer sales. This engagement included enhancing farmer knowledge about packaging, pricing, outreach, presentation, and other market proficiencies.

The most recent National Farm Training Incubator Farm Training Initiative's regional report highlights multiple major goals and challenges to incubator farms in the Midwest region (Tufts University, 2016). The report explicitly stated that the goals for incubator farms were to increase access to program materials (land, funding, staffing) and to increase collaborations (for funding and training) throughout the region. Specific challenges to the Midwest region were supporting limited resource farmers and managing competition with local growers. This study is especially in conversation with the challenges relating to supporting limited resource farmers. It is clear is that more research is needed to examine the role that social connectedness plays in the long-term success of emerging farmers as nascent entrepreneurs. The language barriers facing refugee farmers, in particular, merit closer examination for enhanced programming and engaged policy-making. This research also highlights the usefulness of utilizing mixed-method network analysis to examine market access among farmers and the effective application of this method within an incubator farm setting. Emerging farmers possess a tremendous amount of potential to bring about positive changes in local food systems and contribute to the vibrancy of communities. It is hoped that this case study and similar efforts will contribute toward supporting emerging farmers with evidence-based policymaking and inclusive agricultural development.

\section{Acknowledgments}

We are grateful for the support from the Greater Lansing Food Bank's Lansing Roots staff and volunteers. We are also thankful for the support of Rebecca Titus for her help in piloting the interview guide. Finally, we are most thankful of the study participants and all of the farmers at Lansing Roots; without their help, the study would not have been possible.

\section{References}

Ahearn, M C. (2013). Beginning farmers and ranchers at a glance (Economic Bulletin No. 22). Washington, DC: U.S. Department of Agriculture. https://doi.org/10.2139/ssrn.2266443

Aldrich, H. E. (2005). Entrepreneurship. In N. Smelser \& R. Swedberg (Eds.), The handbook of economic sociology (2nd edition, pp. 451-477). Princeton, NJ: Princeton University Press. https://doi.org/10.1515/9781400835584.451

Aldrich, H. E., \& Zimmer, C. (1986). Entrepreneurship through social networks. In D. L. Sexton \& R. W. Smilor (Eds.), The art and science of entrepreneurship (pp. 3-23). Cambridge, MA: Ballinger.

Alkon, A. H., \& Agyeman, J. (2011). Cultivating food justice: Race, class, and sustainability. Cambridge, MA: MIT Press. https://doi.org/10.7551/mitpress/8922.001.0001

Allen, P., \& Sachs, C. (2007). Women and food chains: The gendered politics of food. International Journal of Sociology of Food and Agriculture, 15(1), 1-23. https://doi.org/10.48416/ijsaf.v15i1.424

Andreatta, S., \& Wickliffe, W. (2002). Managing farmer and consumer expectations: A study of a North Carolina farmers market. Human Organization, 61(2), 167-176. https://doi.org/10.17730/humo.61.2.a4g01d6q8dji5lkb

Ashby, J., Heinrich, G., Burpee, G., Remington, T., Wilson, K., Quiros, C. A., ... Ferris, S. (2009). What farmers want: Collective capacity for sustainable entrepreneurship. International Journal of Agricultural Sustainability, 7(2), 130-146. https://doi.org/10.3763/ijas.2009.0439

Bandiera, O., \& Rasul, I. (2006). Social networks and technology adoption in Northern Mozambique. The Economic Journal, 116(514), 869-902. https://doi.org/10.1111/j.1468-0297.2006.01115.x

Bell, M. M. (2004). Farming for us all: Practical agriculture and the cultivation of sustainability. University Park, PA: Pennsylvania State University Press.

Beus, C. E., \& Dunlap, R. E. (1990). Conventional versus alternative agriculture: The paradigmatic roots of the debate. Rural Sociology, 55(4), 590-616. https://doi.org/10.1111/j.1549-0831.1990.tb00699.x 
Bloom, L., \& Riemer, R. (1949). Removal and return: The socio-economic effects of the war on Japanese-Americans. Berkley, CA: University of California Press.

Borgatti, S. P., Everett, M. G., \& Johnson, J. C. (2013). Analyzing social networks. London, UK: Sage Publications.

Brasier, K. J., Sachs, C. E., Kiernan, N. E., Trauger, A., \& Barbercheck, M. E. (2014). Capturing the multiple and shifting identities of farm women in the northeastern United States. Rural Sociology, 79(3), 283-309. https://doi.org/10.1111/ruso.12040

Brown, C., \& Miller, S. (2008). The impacts of local markets: A review of research on farmers markets and community supported agriculture (CSA). American Journal of Agricultural Economics, 90(5), 1298-1302. https://doi.org/10.1111/i.1467-8276.2008.01220.x

Brown, P. L. (2011, October 9). When the uprooted put down roots. The New York Times. https://www.nytimes.com/2011/10/10/us/refugees-in-united-states-take-up-farming.html

Burt, R. S. (1993). The social structure of competition. In R. Swedberg (Ed.), Explorations in Economic Sociology (pp. 65103). New York: Russell Sage Foundation.

Burt, R. S. (1995). Structural holes: The social structure of competition. Cambridge, MA: Harvard University Press.

Burt, R. S., \& Merluzzi, J. (2014). Embedded brokerage: Hubs versus locals. In Contemporary perspectives on organizational social networks (Research in the Sociology of Organizations, Vol. 40) (pp. 161-177). Emerald Group Publishing Limited. https://doi.org/10.1108/S0733-558X(2014)0000040008

Callon, M. (1998). Introduction: The embeddedness of economic markets in economics. In M. Callon (Ed.), The Laws of the Markets (pp. 1-57). Oxford, UK: Blackwell Publishers. https://doi.org/10.1111/j.1467-954X.1998.tb03468.x

Calo, A. (2020). The Yeoman myth: A troubling foundation of the beginning farmer movement. Gastronomica, 20(2), 12-29. https://doi.org/10.1525/gfc.2020.20.2.12

Calo, A., \& De Master, K. T. (2016). After the incubator: Factors impeding land access along the path from farmworker to proprietor. Journal of Agriculture, Food Systems, and Community Development, 6(2), 111-127. https://doi.org/10.5304/jafscd.2016.062.018

Centola, D., \& Macy, M. (2007). Complex contagions and the weakness of long ties. American Journal of Sociology, 113(3), 702-734. https://doi.org/10.1086/521848

Chiappe, M. B., \& Flora, C. B. (1998). Gendered elements of the alternative agriculture paradigm. Rural Sociology, 63(3), 372-393. https://doi.org/10.1111/j.1549-0831.1998.tb00684.x

Christensen, L. O., \& O’Sullivan, R. (2015). Using social networking analysis to measure changes in regional food systems collaboration: A methodological framework. Journal of Agriculture, Food Systems, and Community Development, 5(3), 113-129. https://doi.org/10.5304/jafscd.2015.053.013

Coleman, J. S. (1990). Foundations of social theory. Cambridge, MA: Harvard University Press.

Creswell, J. W. (2003). Research design: Qualitative, quantitative, and mixed methods approaches. Thousand Oaks, CA: Sage Publications.

Creswell, J. W., Plano Clark, V. L., Gutmann, M. L., \& Hanson, W. E. (2003). Advanced mixed methods research designs. In A. Tashakkori \& C. Teddlie (Eds.), Handbook of mixed methods in social and behavioral research (pp. 209-240). Thousand Oaks, CA: Sage Publications.

DeLind, L. B. (1999). Close encounters with a CSA: The reflections of a bruised and somewhat wiser anthropologist. Agriculture and Human V alues, 16(1), 3-9. https://doi.org/10.1023/A:1007575521309

DeLind, L. B. (2006). Of bodies, place, and culture: Re-situating local food. Journal of Agricultural and Environmental Ethics, 19, 121-146. https://doi.org/10.1007/s10806-005-1803-z

Dubini, P., \& Aldrich, H. (1991). Personal and extended networks are central to the entrepreneurial process. Journal of Business Venturing, 6(5), 305-313. https://doi.org/10.1016/0883-9026(91)90021-5

Ewert, B. M. (2012). Understanding incubator farms: Innovative programs in new farmer development (Master's thesis). University of Montana, Missoula, MT. Retrieved from https://scholarworks.umt.edu/etd/1146

Fairlie, R. W., \& Robb, A. M. (2009). Gender differences in business preformance: Evidence from the Characteristics of Business Owners survey. Small Business Economics, 33(4), 375-395. https://doi.org/10.1007/s11187-009-9207-5

Feld, S. L. (1981). The focused organization of social ties. American Journal of Sociology, 86(5), 1015-1035. https://doi.org/10.1086/227352 
Fennelly, K. (2004). Listening to the experts: Provider recommendations on the health needs of immigrants and refugees (Willy Brandt Series of Working Papers in International Migration and Ethnic Relations No. 1/04). Malmö, Sweden: Malmö University. Retrieved from http://muep.mau.se/handle/2043/688

Flora, C. B., McIsaac, G., Gasteyer, S., \& Kroma, M. (2001). Farm-community entrepreneurial partnerships in the Midwest. In C. Flora (Ed.), Interactions between agroecosystems and rural comunities (pp. 115-130). New York: CRC Press. https://doi.org/10.1201/9781420041385.ch9

Flora, J. L., Emery, M., Thompson, D., Prado-Meza, C. M., \& Flora, C. B. (2012). New immigrants in local food systems: Two Iowa cases. The International Journal of Sociology of Agriculture and Food, 19(1), 119-134. https://doi.org/10.48416/ijsaf.v19i1.240

Giannella, E., \& Fischer, C. S. (2016). An inductive typology of egocentric networks. Social Networks, 47, 15-23. https://doi.org/10.1016/i.socnet.2016.02.003

Gist, M. E., \& Mitchell, T. R. (1992). Self-efficacy: A theoretical analysis of its determinants and malleability. The Academy of Management Review, 17(2), 183-211. https://doi.org/10.5465/amr.1992.4279530

Government of Canada, \& Policy Research Initiative. (2005). Social capital as a public policy tool: Project report. Ottawa, Canada. http://dx.doi.org/10.11575/PRISM/10632

Granovetter, M. S. (1973). The strength of weak ties. American Journal of Sociology, 78(6), 1360-1380. https://doi.org/10.1086/225469

Granovetter, M. (1974). Getting a job: A study of contacts and careers. Chicago, IL: University of Chicago Press.

Greater Lansing Food Bank. (n.d.). Programs: Lansing Roots. Retrieved from https://greaterlansingfoodbank.org/programs/programs

Greene, P. G., Brush, C. G., \& Gatewood, E. J. (2007). Perspectives on women entrepreneurs: Past findings and new directions. In M. Minniti (Ed.), Entrepreneurship: The engine of growth, Vol. 1 (pp. 181-204). Westport, CT: Praeger Publisher.

Halpern, P. (2008). Refugee economic self-sufficiency: An exploratory study of approaches used in office of refugee resettlement programs. Washington, DC: U.S. Department of Health and Human Services. Retrieved from https://aspe.hhs.gov/basicreport/refugee-economic-self-sufficiency-exploratory-study-approaches-used-office-refugee-resettlement-programs

Hassanein, N. (1997). Networking knowledge in the sustainable agriculture movement: Some implications of the gender dimension. Society and Natural Resources, 10(3), 251-257. https://doi.org/10.1080/08941929709381024

Hayden, J., Rocker, S., Phillips, H., Heins, B., Smith, A., \& Delate, K. (2018). The importance of social support and communities of practice: Farmer perceptions of the challenges and opportunities of integrated crop-livestock systems on organically managed farms in the northern U.S. Sustainability, 10(12), 4606. https://doi.org/10.3390/su10124606

Herz, A., Peters, L., \& Truschkat, I. (2014). How to do qualitative structural analysis: The qualitative interpretation of network maps and narrative interviews. Forum: Qualitative Social Research, 16(1). https://doi.org/10.17169/FQS-16.1.2092

Hightower, L. S., Niewolny, K. L., \& Brennan, M. A. (2013). Immigrant farmer programs and social capital: Evaluating community and economic outcomes through social capital theory. Community Development, 44(5), 582-596. https://doi.org/10.1080/15575330.2013.838975

Hinrichs, C. C. (2000). Embeddedness and local food systems: Notes on two types of direct agricultural market. Journal of Rural Studies, 16(3), 295-303. https://doi.org/10.1016/S0743-0167(99)00063-7

Hinrichs, C. C. (2003). The practice and politics of food system localization. Journal of Rural Studies, 19(1), 33-45. https://doi.org/10.1016/S0743-0167(02)00040-2

Jarosz, L. (2000). Understanding agri-food networks as social relations. Agriculture and Human Values, 17(3), $279-283$. https://doi.org/10.1023/A:1007692303118

Jarosz, L. (2011). Nourishing women: Toward a feminist political ecology of community supported agriculture in the United States. Gender, Place and Culture, 18(3), 307-326. https://doi.org/10.1080/0966369X.2011.565871

Jenssen, J. I. (1999). Entrepreneurial networks: A study of the impact of social networks and resource access on the start-up of new organizations (Doctoral dissertation). Norges Handelshoyskole. 
Katchova, A. L., \& Ahearn, M. C. (2016). Dynamics of farmland ownership and leasing: Implications for young and beginning farmers. Applied Economic Perspectives and Policy, 38(2), 334-350. https://doi.org/10.1093/aepp/ppv024

Knowler, D., \& Bradshaw, B. (2007). Farmers' adoption of conservation agriculture: A review and synthesis of recent research. Food Policy, 32(1), 25-48. https://doi.org/10.1016/j.foodpol.2006.01.003

Kodithuwakku, S. S., \& Rosa, P. (2002). The entrepreneurial process and economic success in a constrained environment. Journal of Business Venturing, 17(5), 431-465. https://doi.org/10.1016/S0883-9026(01)00074-X

Krebs, V., \& Holley, J. (2006). Building smart communities through network weaving. Athens, OH: Appalachian Center for Economic Networks. Retrieved from https://community-wealth.org/content/building-smart-communities-through-network-weaving

Kuratko, D. F. (2016). Entrepreneurship: Theory, process, and practice. Boston, MA: Cengage Learning.

Laverentz, L., \& Krotz, D. (2012). Refugee agricultural partnership program: The lessons and challenges after five years. Washington, DC: U.S. Department of Health and Human Services.

Li, P. S. (2004). Social capital and economic outcomes for immigrants and ethnic minorities. Journal of International Migration and Integration, 5(2), 171-190. https://doi.org/10.1007/s12134-004-1008-8

Liepins, R. (1998). "Women of broad vision": Nature and gender in the environmental activism of Australia's 'Women in Agriculture' movement. Environment and Planning A, 30(7), 1179-1196. https://doi.org/10.1068/a301179

Lin, N., Ensel, W. M., \& Vaughn, J. C. (1981). Social resources and strength of ties: Structural factors in occupational status attainment. American Sociological Review, 46(4), 393-405. https://doi.org/10.2307/2095260

Lorrain, F., \& White, H. C. (1971). Structural equivalence of individuals in social networks. The Journal of Mathematical Sociology, 1(1), 49-80. https://doi.org/10.1080/0022250X.1971.9989788

Macy, B. (2019, June 6). Somali Bantu refugees farm for a better life. The Roanoke Times. Retrieved from https://roanoke.com/archive/somali-bantu-refugees-farm-for-a-better-life/article a912b3af-cb79-5640-8b118537e6319079.html

Mailfert, K. (2007). New farmers and networks: How beginning farmers build social connections in France. Tijdschrift Voor Economische En Sociale Geografie, 98(1), 21-31. https://doi.org/10.1111/j.1467-9663.2007.00373.x

Marsden, P. V. (1990). Network data and measurement. Annual Review of Sociology, 16, 435-463. https://doi.org/10.1146/annurev.so.16.080190.002251

Marsden, P. V. (2002). Egocentric and sociocentric measures of network centrality. Social Networks, 24(4), 407-422. https://doi.org/10.1016/S0378-8733(02)00016-3

McGehee, N. G. (2007). An agritourism systems model: A Weberian perspective. Journal of Sustainable Tourism, 15(2), 111-124. https://doi.org/10.2167/jost634.0

McGregor, J., \& Tweed, D. (2002). Profiling a new generation of female small business owners in New Zealand: Networking, mentoring and growth. Gender, Work and Organization, 9(4), 420-438. https://doi.org/10.1111/1468-0432.00167

Minniti, M. (2009). Gender issues in entrepreneurship. Foundations and Trends in Entrepreneurship, 5(7-8), 497-621. https://doi.org/10.1561/0300000021

Mishra, A. K., El-Osta, H. S., \& Shaik, S. (2010). Succession decisions in U.S. family farm businesses. Journal of Agricultural and Resource Economics, 35(1), 133-152. https://www.jstor.org/stable/23243041

Montri, D., Chung, K., \& Behe, B. (2021). Farmer perspectives on farmers markets in low-income urban areas: A case study in three Michigan cities. Agriculture and Human Values, 38, 1-14. https://doi.org/10.1007/s10460-020-10144-3

Morland, K., \& Wing, S. (2007). Food justice and health in communities of color. In R. D. Bullard (Ed.), Growing smarter: Achieving livable communties, envrironmental justice, and regional equity (pp. 171-188). Cambridge, MA: MIT Press. https://doi.org/10.7551/mitpress/3375.003.0013

Morris, M. D., Popper, S. T., Rodwell, T. C., Brodine, S. K., \& Brouwer, K. C. (2009). Healthcare barriers of refugees post-resettlement. Journal of Community Health, 34(6), 529-538. https://doi.org/10.1007/s10900-009-9175-3

Niewolny, K. L., \& Lillard, P. T. (2010). Expanding the boundaries of beginner farmer training and program development: A review of contemporary initiatives to cultivate a new generation of American farmers. Journal of Agriculture, Food Systems, and Community Development, 1(1), 65-88. https://doi.org/10.5304/jafscd.2010.011.010 
O’Hara, S. U., \& Stagl, S. (2001). Global food markets and their local alternatives: A socio-ecological economic perspective. Population and Environment, 22(6), 533-554. https://doi.org/10.1023/A:1010795305097

Ostrom, M., Cha, B., \& Flores, M. (2010). Creating access to land grant resources for multicultural and disadvantaged farmers. Journal of Agriculture, Food Systems, and Community Development, 1(1), 89-105. https://doi.org/10.5304/jafscd.2010.011.011

Panopoulos, J. (2013). New farms for new Americans: Incubator farm programs, economic self-sufficiency and grant dependency (Unpublished thesis). University of Vermont, Burlington.

Peterson, H., Barkley, A., Chacón-Cascante, A., \& Kastens, T. (2012). The motivation for organic grain farming in the United States: Profits, lifestyle, or the environment? Journal of Agricultural and Applied Economics, 44(2), 137-155. https://doi.org/10.1017/S1074070800000237

Portes, A. (1998). Social capital: Its origins and applications in modern sociology. Annual Review of Sociology, $24,1-24$. https://doi.org/10.1146/annurev.soc.24.1.1

Poulsen, M. N. (2017). Cultivating citizenship, equity, and social inclusion? Putting civic agriculture into practice through urban farming. Agriculture and Human V alues, 34(1), 135-148. https:/ / doi.org/10.1007/s10460-016-9699-y

Prokopy, L. S., Floress, K., Klotthor-Weinkauf, D., \& Baumgart-Getz, A. (2008). Determinants of agricultural best management practice adoption: Evidence from the literature. Journal of Soil and Water Conservation, 63(5), 300-311. https://doi.org/10.2489/jswc.63.5.300

Putnam, R. D., Leonardi, R., \& Nanetti, R. Y. (1994). Making democracy work: Civic traditions in modern Italy. Princeton, NJ: Princeton University Press. https://doi.org/10.1515/9781400820740

Rhodes, W., \& Joseph, H. (2004). Immigrant and refugee farming programs and resources: A guide to projects, people, places, publications and other information. Boston, MA: New Entry Sustainable Farming Project, Agriculture, Food and Environment Program, Tufts University.

Rogers, E. M. (2003). Diffusion of innovations (5th ed.). New York, NY: Free Press.

Sachs, C. E. (1995). Gendered fields: Rural woman, agriculture, and environment. Boulder, CO: Westview Press.

Sachs, C. E., Barbercheck, M. E., Brasier, K. J., Kiernan, N. E., \& Terman, A. R. (2016). The rise of women farmers and sustainable agriculture. Iowa City, IA: University of Iowa Press. https://doi.org/10.2307/j.ctt20p57gr

Sanders, J. M., \& Nee, V. (1996). Immigrant self-employment: The family as social capital and the value of human capital. American Sociological Review, 61(2), 231-249. https://doi.org/10.2307/2096333

Schiebel, W. (2005). Entrepreneurial personality traits in managing rural tourism and sustainable business. In D. Hall, I. Kirkpatrick, \& M. Mitchell (Eds.), Rural tourism and sustainable business (pp. 287-304). Clevedon, UK: Channel View Publications. https://doi.org/10.21832/9781845410131-019

Schwartz, E. B. (1976). Entrepreneurship: A new female frontier. Journal of Contemporary Business, 5, 47-76.

Scott, C. K. (2016). The role of emerging farmers' personal networks in market access and start-up farm success (Master's thesis). Michigan State University, East Lansing. https://doi.org/10.25335/M5WH6K

Smith-Doerr, L., \& Powell, W. W. (2005). Networks and economic life. In N. Smelser \& R. Swedberg (Eds.), The handbook of economic sociology (2nd Ed., pp. 379-402). Princeton, NJ: Princeton University Press. https://doi.org/10.1515/9781400835584.379

Spielman, D. J., Davis, K., Negash, M., \& Ayele, G. (2011). Rural innovation systems and networks: Findings from a study of Ethiopian smallholders. Agriculture and Human V alues, 28(2), 195-212. https://doi.org/10.1007/s10460-010-9273-y

Stephenson, G. (2003). The somewhat flawed theoretical foundation of the extension service. Journal of Extension, 41(4), Art. 4FEA1. Retrieved from https://archives.joe.org/joe/2003august/a1.php

Swedberg, R. (2000). Entrepreneurship: The social science view. Oxford, UK: Oxford University Press.

Swedberg, R. (2003). Principles of economic sociology. Princeton, NJ: Princeton University Press. https://doi.org/10.1515/9781400829378

The Pennsylvania State University. (n.d.). About PA-WAgN. Retrieved August 13, 2019, from https://agsci.psu.edu/wagn/directory/about-pa-wagn 
Thilmany McFadden, D., Conner, D., Deller, S., Hughes, D., Meter, K., Morales, A. A., ... Tropp, D. (2016). The economics of local food systems: A toolkit to guide community discussions, assessments and choices. Retrieved from https://www.ams.usda.gov/publications/content/economics-local-food-systems-toolkit-guide-communitydiscussions-assessments

Thornton, P. H. (1999). The sociology of entrepreneurship. Annual Review of Sociology, 25, 19-46. https://doi.org/10.1146/annurev.soc.25.1.19

Trauger, A. (2004). "Because they can do the work": Women farmers in sustainable agriculture in Pennsylvania, USA. Gender, Place and Culture, 11(2), 289-307. https://doi.org/10.1080/0966369042000218491

Trauger, A. K. (2005). Social, economic, and environmental justice: A network analysis of sustainable agriculture in Pennsylvania (Doctoral dissertation). Pennsylvania State University. Retrieved from https://etda.libraries.psu.edu/catalog/6521

Tufts University. (2016). National incubator farm training initiative's regional report. Boston, MA: Friedman School of Nutrition Science and Policy, Tufts University. Retrieved from https://nesfp.org/food-systems/national-incubator-farm-training-initiative/national-incubator-map

U.S. Department of Health \& Human Services. (2012). Refugee agricultural partnership program: FY 2011 annual report. Washington, DC: U.S. Department of Health \& Human Services. Retrieved from https://www.acf.hhs.gov/orr/programs/rapp/about

Uzzi, B. (1997). Social structure and competition in interfirm networks: The paradox of embeddedness. Administrative Science Quarterly, 42(1), 35-67. https://doi.org/10.2307/2393808

Waldinger, R., Aldrich, H., \& Ward, R. (1990). Ethnic entrepreneurs: Immigrant business in industrial societies. Newbury Park, CA: Sage Publications.

Wasserman, S., \& Faust, K. (1994). Social network analysis: Methods and applications. New York, NY: Cambridge University Press. https://doi.org/10.1017/CBO9780511815478

Weber, C., \& Kratzer, J. (2013). Social entrpreneurship, social networks and social value creation: A quantitative analysis among social entrepreneurs. International Journal of Entrepreneurial Venturing, 5(3), 217-239. https://doi.org/10.1504/IJEV.2013.055291

Wells, B. L., \& Gradwell, S. (2001). Gender and resource management: Community supported agriculture as caringpractice. Agriculture and Human Values, 18(1), 107-119. https://doi.org/10.1023/A:1007686617087

White, H. C., Boorman, S. A., \& Breiger, R. L. (1976). Social structure from multiple networks. American Journal of Sociology, 81(4), 730-780. https://doi.org/10.1086/226141

Wilson, K. L., \& Martin, W. A. (1982). Ethnic enclaves: A comparison of the Cuban and Black economies in Miami. American Journal of Sociology, 88(1), 135-160. https://doi.org/10.1086/227637

Wilson, K. L., \& Portes, A. (1980). Immigrant enclaves: An analysis of the labor market experiences of Cubans in Miami. American Journal of Sociology, 86(2), 295-319. https://doi.org/10.1086/227240

Witt, P. (2004). Entrepreneurs' networks and the success of start-ups. Entrepreneurship and Regional Development, 16(5), 391-412. https://doi.org/10.1080/0898562042000188423 